\title{
12
}

\section{Public Administration Reform in Vietnam: foreign transplants or local hybrids?}

\author{
Martin Painter
}

[Reform]...must be started from the practices of Vietnam, of its characteristics, its national traditions; concurrently it must consult and learn from the international achievements and experience. But it must not absolutely copy them and apply them exactly, as this would be harmful for the interest of the nation (Do Muoi 1995).

...[G]lobal capitalism, far from simply threatening the Vietnamese state, is supplying an arsenal of techniques by which state-directed cultural borrowing will salvage and refine a managerial regime whose previous policies had seriously tarnished it (Woodside 1997:74)

Vietnam is in the midst of a process of fundamental state restructuring prompted by the abandonment of the command economy and the adoption of a long-term strategy of doi moi ('renovation') that essentially entails market reform and integration with the world economy. In the process, the Vietnamese government has embarked on a substantial public administration reform (PAR) program. The public administration reform program was basically initiated with the launch of doi moi at the Sixth Party Congress of 1986, but it was formally given the status of a coordinated national program at the Eighth Plenum of the Seventh Party Congress in January 1995. Following a major review in 2000, the government decided in September 2001 to set out a Master Program on Public Administration Reform for the Period 2001-2010, with four key reform areas (institutional reform, organisational structures, civil service reform and public finance). Different government agencies were responsible for seven programs within these four areas, and implementation plans and subprograms were drawn up and fleshed out (UNDP 2001, 2002).

The Master Program summarises the problems and makes proposals for reform within the broad framework of a move towards 'a market-oriented economy with a 
socialist orientation'. The program identifies the Soviet-style 'centralized and subsidized bureaucratic management system' as a major cause of many problems (Government of Vietnam 2001:2), with pre-existing procedures, structures and habits continuing to hold back the adaptation of public administration to the new environment. Administrative structures are 'overlapping...inconsistent... centralized and compartmentalized', while 'administrative procedures are cumbersome and complex' and 'administrative order and discipline are loose'. '[A]ppropriate financial mechanisms', it finds, do not exist for the operation of public service and administrative agencies. Cadres and civil servants lack skills, professionalism and ethical standards, and corruption and 'harassment for bribes' remain a 'rather serious' problem.

The main focus of this chapter is on the origins of, and reasons for, the selection and adoption of reform ideas and proposals as a solution to these problems. Here, we consider two sources of reform ideas in particular: first, Party doctrine as it has evolved within the context of recent Vietnamese development; and second, external, 'global' models of administrative reform. ${ }^{1}$ The Master Program is quite explicit about the significance of both these sources, stressing, first, the Party's role in articulating theories and practical issues and, second, that public administration reform 'must benefit from appropriate application of international knowledge and experience of organization and management operations' (Government of Vietnam 2001:3).

Thus, on the one hand, parts of the document bear the stamp of contemporary critical 'insider' reviews of the role of the Party, including the manner in which it should 'renovate' itself consistent with its socialist traditions, and current reflections on the developing role of the state under the doctrine of democratic centralism.

- The reform and perfection of public administration will be closely linked to the building and rectification of the Party, the renovation of the contents and leading modalities of the Party over the state in general and public administration in particular...(Government of Vietnam 2001:7)

- Administrative agencies and civil servants should place themselves under close supervision by people. There must be effective measures to curb acts which violate democracy and freedom and which indulge in arbitrariness, red tape, corruption, harassment for bribes and trouble-making to people (Government of Vietnam 2001:7)

- PAR policies...should encourage...the maintenance of order and discipline in economic activities to promote the economic growth and improve the people's life (Government of Vietnam 2001:7)

- ...implement the grassroots democracy regulation...whereby leading officials... at the various levels will be required to periodically and directly meet and talk with people and businesses (Government of Vietnam 2001:9)

- The state will develop policies, mechanisms to enable social organisations, mass organisations and the people themselves to deliver directly services which serve production and living requirements (Government of Vietnam 2001:16) 
On the other hand, Vietnam is hungry for ideas, and in the world of administrative reform there is no shortage. Armies of consultants hired by aid donors promote apparently consensual 'best practice' global models (Larmour 2002). ${ }^{2}$ To add to their weight and authority, international agencies such as the OECD and World Bank give these ideas their seal of approval (Common 2001). This global exchange of reform ideas increases policy diffusion and 'transfer' (Bennett 1991; Dolowitz and Marsh 1996; Halligan 1996). Not surprisingly then, the 'menu' of proposals and solutions shows a strong trace of conventional global public administration reform discourse. ${ }^{3}$

- Functions and duties of heads of institutions will be clearly established whereby they will be responsible and accountable for the performance and results of the institutions which they head (Government of Vietnam 2001:12).

- The mechanism for decentralising financial and budgetary management will be reformed to ensure unity of the national financial management system...(and) promote localities' and sectors' proactiveness, dynamism, creativity and accountability...a mechanism for calculating budget requirements on the basis of outputs and quality of operations, ensuring the monitoring of outputs, quality of targets and objectives (Government of Vietnam 2001:16).

- The salary system will be reformed in line with a new concept...fully monetising salaries...a salary-related allowance scheme...a system of bonuses for excellent services (Government of Vietnam 2001:14).

- A number of activities and public services, which are not necessarily handled by government agencies, should be transferred to enterprises, social organisations, private... and non-government organisations (Government of Vietnam 2001:5-6).

- ...encourage investors to invest in the development of...education institutions and...high quality hospitals...Contracting out mechanism will be applied to some...services (Government of Vietnam 2001:17).

Since the reform proposals in the public administration program stem from different sources, several important questions remain. First, is this all rhetoric, or 'reform talk', governed by the need to pay lip-service to one or more sets of doctrine? Second, in so far as the substance of the 'talk' relates to proposals for action, what factors lie behind the appropriateness and attractiveness of particular proposals? Third, are 'foreign ideas' carefully and systematically filtered through a prism of Communist Party doctrine? Is consistency or coherence required? And finally, how are solutions adapted to a local set of problems when taken 'out of context'?

Here, we have two quite distinct issues to address. The first is the fate of solutions with origins in Communist Party doctrine in a context of reform proposals that address problems of 'marketisation'; and the second is the fate of solutions drawn from the wider global discourse when they are applied in the specific context of development and transition being experienced in Vietnam. If parts of the menu are familiar, are the dishes the same? And what sort of meal do they produce? 


\section{GARBAGE CANS AND TRANSPLANTS}

A useful starting point is John Kingdon's (1984) application of 'garbage can' theories of organisation (Cohen, March and Olsen 1972). In this view, the reform process can be considered as three separate streams of action: a 'problem stream', a 'policy stream' and a 'politics stream'. Reform is not so much a rational decision-making process in which problems are first identified and solutions then sought, but a more disjointed set of events in which the nature and significance of problems are contested in the 'problem stream', and solutions currently found in the policy stream become attached to some of them as a result of events in the politics stream. In the policy stream, ideologues, policy experts and advocates explore and contest ideas and proposals. The separate streams have a life of their own, and solutions look for problems as much as problems give rise to a search for solutions. Ideas and doctrines about administrative improvement emerge in the policy stream independently of administrative problems, and the way they are connected is somewhat random. An important part of this process of attaching solutions to problems is rationalisation of the 'choice', meaning that the process of justification is as much retrospective and rhetorical as it is prospective and analytical. Means-end rationality-whether it is in the form of Party doctrine or management theory-is suborned to the purpose of justifying a particular, convenient attachment of solution to problem.

This depiction of the meeting of solutions and problems shares similarities with Alan Watson's (2001) analysis of the transplantation and borrowing of legal ideas. Watson also suggests that a somewhat serendipitous process is at work in this process: fashions come and go, local reformers pick and choose what seems like a 'good idea' from the contemporary scene for reasons that are none too systematic, and much of what is transplanted (often for reasons of political convenience) subsequently lies on the surface of a set of social processes from which it can remain disconnected. The 'substance' of what is borrowed is not necessarily linked to the reason for its adoption (Watson 2001). Similarly, the manner in which contemporary administrative reform ideas and recipes are picked up in different jurisdictions seems by most accounts to be a somewhat haphazard affair. Nils Brunsson (1998:264), for example, calls the phenomenon of simultaneous adoption of contemporary reform proposals 'cropping up'. As he describes it, the adoption of new organisational forms in a number of places simultaneously is as much in the realm of 'talk' as in the realm of instrumental problem-solving and action (in Brunsson's 'garbage can' view of organisational life, 'talk' and 'action' are frequently 'de-coupled'). Rationalisation through expounding a reform discourse is a very large part of reform activity, which is principally about future intentions and hopes. How the adopted solutions actually affect local practices is another story (Brunsson 1998) - whatever is borrowed is also 'transformed' as it is adapted to a local political or administrative culture (Christensen and Laegreid 2001). The result of the transplants is a set of new hybrids. 
One objection to this approach is that it seems to trivialise the importance of reform as 'problem solving'. In Vietnam, reform is a central political priority because the regime's survival depends on its success. The process brings to the surface a long list of deep and urgent policy problems. On the one hand, these imbue the reform agenda with an especial urgency, which may seem to offer a stern test of the approach outlined above, in particular the proposition that the process is best understood as a somewhat haphazard connection of solutions with problems. On the other hand, the heightened need for successful problem solving is precisely the condition under which the somewhat random and serendipitous attachment of ready-made solutions-including foreign transplants-might become more common. The intensity of solution advocacy as an independent stream of activity in such a situation also increases. Similarly, the Party's production lines of doctrinal affirmation and renovation shift rapidly through the gears as the lengthening list of problems pose new puzzles. As the pressure to adopt solutions becomes more urgent, this urgency may prompt the Party to lower its ideological resistance to particular solutions and subsequently to find new forms of rationalisation.

The analysis presented here begins with a broad historical overview of the evolution of the public administration reform program as interconnected streams of problems and solutions. This draws on official accounts given by Vietnamese public officials about the nature, aims and achievements of the reform process, both when the reforms were announced and retrospectively. These accounts reflect on both the nature of the problems - the diagnosis - and the justifications for the solutions. The data are drawn to a large degree from an official comprehensive review undertaken in 2000, with the close involvement of senior officials in the central agency concerned most with public administration reform, namely the Government Committee for Organization and Personnel (now the Ministry for Home Affairs). ${ }^{4}$ This approach has its limitations, of course: any text has its own purposes and cannot be treated simply as a piece of 'objective evidence', and every text has an inner history that can rarely be recounted. With these limitations in mind, the analysis also pursues a case study strategy, looking at a range of interconnected issues underlying and associated with salary reform, one of the seven public administration reform programs. This brief case study draws on additional sources, including media reports, documents released by the government and other sources, and discussions with officials and government advisors.

What is presented here, however, is only one 'take' on the reform process. Separate attention needs also to be given to the political factors that are at play in giving priority to one set of problems and, at the same time, to a parallel set of solutions. Observing some of the products of these political struggles-official statements of intent, government decisions and announced programs of particular administrative reform - the discussion and analysis in this chapter seek to provide some glimpses of the subtle interplay of local agendas and foreign transplants in administrative reform in Vietnam. The account stops short of looking at the implementation and 
outcome of reforms.

\section{UNDERLYING THEMES OF PUBLIC ADMINISTRATION REFORM IN VIETNAM}

The underlying purposes of public administration reform in Vietnam are derived from a set of quite particular local circumstances and problems. The core of the issue, according to most public officials, is the transformation of the state from one that managed a command economy to one that seeks to regulate a 'multi-sector' economy. Public administration reform is officially perceived as one of the core elements of doi moi, and is traced back to the same origins. The Sixth Party Congress of 1986, when the doi moi program was launched, stated the need to 'carry out a major reform of the organizational structure of the state machinery' by (among other things) creating a 'unified system, with clear definition/separation of jurisdictions...according to the principle of democratic centralism; distinguishing between functions of economic-administration management and productionbusiness management' and 'a lean apparatus with.... contingent of officials and civil servants who are politically qualified and competent in state management and socio-economic management' (quoted in Government Steering Committee 2000b:8). The Sixth Party Plenum in March 1989 newly emphasised that 'the state has to...manage all activities in social life by laws and in accordance with the Party's direction and policies'.

In the early 1990s, a number of measures were implemented, including a reduction in the number of administrative units at central and local levels, the introduction of a Civil Service Ordinance in 1993 and re-drafting of legal documents. Further important changes to the structure of government were brought in under the new 1992 Constitution, such as setting out a clearer distinction between the executive, legislative and judicial arms of the state machinery, defining the powers and responsibilities of state offices such as that of prime minister, and specifying more clearly the relationships between them. This marked a clearer delineation of authority, replacing a tradition of diffuse power sharing and collective leadership. At the same time, the leadership role of the Party was clearly re-affirmed, albeit within the context of a 'state ruled by law'. A report to the Second Session of the Ninth National Assembly in December 1992 highlighted this second element

In principle, the national administration must be institutionalized and regulated by the system of administrative laws to govern the relations arising in the process of state management [emphasis in original] (Government Steering Committee 2000b:14).

This growing formalisation and rule-governed nature of administrative practices was a broad umbrella under which a number of specific administrative measures advanced, for example anti-corruption efforts, simplification of overlapping administrative jurisdictions, monetisation of $a d$ hoc reward systems, and 'bringing to account' off-budget fees and charges. The underlying agenda, however, was 
tempered by recognition of a set of cross-cutting concerns. As stated in the 1992 report to the National Assembly quoted above

In order to accomplish the objective of PAR, which is to develop an effective and efficient administration and prevent any sign of devolution, and localism, it is important to move towards the democratic administration which is close to the people and responsive to people's needs (Government Steering Committee 2000b:14).

A clear expression of this link between 'democratic' administrative reform and political stabilisation was provided in the resolution of the mid-term Party plenum in January 1994, which set out a set of principles underlining the 'gradual perfection of the State of Vietnam based on rule-of-law' (sic) -

- the state of the people, by the people and for the people, governing all social activities by laws, develops the country under the socialist orientation

- practising socialist democracy

- protecting human rights and basic civil liberties

- mobilising people to the cause of the country's development

- installing orders and rules (Government Steering Committee 2000b:15).

In sum, public administration reform was only in part about efficiency and effectiveness. Of equal, if not greater, concern were order and stability under the Party's political guidance. Development, requiring rationally ordered and efficient state machinery, would also require the mobilisation of consent and of closely monitored group and individual contributions. The prominent references to 'grassroots democracy' and 'close supervision by the people' in the 2001 Master Program continue to reflect this political priority.

The first official recognition of public administration reform as a coherent program came at the Eighth Party Plenum of the Seventh Congress in January 1995. The resolution on public administration reform had three 'fundamental themes'.

- Public administration reform is considered a pressing need and central task in developing and improving the Socialist Republic of Vietnam

- The main objective of public administration reform is to develop a competent, clean and transparent administration that does not abuse its power and is moving towards modernisation effectively and efficiently, to manage the affairs of the state, to promote the healthy development of society in the right direction, to serve the people better, and to develop a rule-of-law routine.

- Public administration reform is...composed of the following three components: institutional reform, re-engineering of the organisational structures... and the development of a contingent of administrative civil servants (Government Steering Committee 2000b:16).

The agenda of administrative reform has continued to be dominated by these responses to the initial 'transition problem', but it has also been affected by a set of issues arising from the course of the reform process itself. The importance of these second-order issues is reflected in the problems created by dismantling the old administrative control and command mechanisms over production units, which 
created a vacuum that was filled by more informal systems of control and ownership. The grant of commercial freedoms resulted in a virtual appropriation of state property by managers, bureaucrats and Party officials. On the one hand, this may have succeeded in releasing productive potential but, on the other hand, the dispersed centres of wealth and power that resulted challenged the authority of the state and the legitimacy of the Party, particularly where they were associated with corruption and other abuses (Beresford 2001; Fforde 1993; Gainsborough 2003; Vasavakul 1996). Similar authority gaps and loss of control were seen in relations between central and provincial governments and within the control and coordination systems of ministries and departments. Thus, the public administration reform agenda as it evolved gained new political significance and reinforcement as a set of measures through which the central Party-state could reassert authority (Vasavakul 1996).

In sum, by 1995 the substance of the public administration reform agenda had been set out and many of the dilemmas and obstacles identified. A series of remedies adapted to the Party's needs and local circumstances were being identified. As second-order issues such as growing corruption came to the fore, the stream of problems grew in volume. Moreover, the interconnectedness of the problems became increasingly apparent. For example, the problem of transition from a state that managed production to a state that managed a 'multi-sectoral economy' and regulated private economic activity was seen in terms of the need to disentangle the state simultaneously from economic micro-management and from some pre-existing forms of social protection and dependency. A conception of the role of the state as manager/funder, but not provider/producer, evolved in a manner that did not distinguish between economic and social policy sectors.

There has been a clear distinction between state management functions pertaining to public power organs and business administration and production pertaining to enterprises and businesses and public services provision pertaining to public professional agencies and units; thus every and each one of them can perform their own right given authority, functions and responsibilities within the overall public administration system. Those functions that do not belong to state management agencies will be transferred to SOEs and professional agencies, especially those functions of direct productive and business administration and management and the provision of public services (Government Steering Committee 2000c:8).

In addition, the reform agenda spoke in one breath of 'equitisation' and 'socialisation' (the word 'privatisation' was quite deliberately not appropriated to the local discourse) and of self-help, or co-production.

The stance and viewpoint of Vietnam is that socialisation of some activities in the public sector, as well as equitisation of a proportion of SOEs, can be by no means considered as privatisation. Socialisation will be conducted under the principle that the work is shared between the State and the people, and the State will take the principal role, exercising State management functions (Government Steering Committee 2000b:18).

Thus, 'socialisation' was conceived as 'the transfer of government work to nongovernment agencies' (Vasavakul 2002:10). As against the traditional style of 'begging and giving' and state subsidy, the 'people's resources' needed to be mobilised for public service delivery, along with 'associations, non-government organisations 
and private sector organisations' (Government Steering Committee 2000a:15). This manner of framing the issue appears as a product of socialist doctrinal traditions that put collective above individual effort and contributions. The 'people's resources', however, were to be both collective and individual-local communities would meet to contribute labour and funds to local road maintenance, and families would pay user fees and charges to support local schools and health centres. Vietnam's burgeoning NGO sector, which was subject to increasing regulation and political oversight in the 1990s, was viewed as a potential participant in this process of socialisation (Vasavakul 2002).

The distinction between the functions of 'state management' on the one hand, and 'production' or 'public service delivery' on the other, received greater attention during the 1990s as demands for public services grew. In the process, 'socialisation' and 'equitisation' as solutions became attached to one cross-cutting problem: the effects of 'state subsidy'. The characterisation of state budgetary support for both economic and social protection as 'subsidy' served to derogate both kinds of public expenditure. Ways were sought to restrain demands for subsidy, and many social expenditures came to be viewed in that light. As discussed later in more detail, the solution was to increase user fees and charges. An overriding 'driver' of this agenda was a strict budget constraint, which was partly a deliberate policy of fiscal prudence that had been adopted as part of the stabilisation strategies in the late 1980s, when Vietnam experienced rampant inflation. The need for restraint was also dictated by weaknesses in a tax system that was only slowly being adapted to the realities of a market economy. Tight fiscal policy was maintained by effective central control over disbursements to spending units, one result of which was increased pressure on local governments to make up the shortfall.

Local governments' share of state expenditure grew from 26 per cent in 1993 to over 43 per cent in 1998 (World Bank 2002a). Local governments increasingly relied on a variety of $a d$ hoc revenue sources, particularly service charges and fees, over which there was quite loose central oversight (probably deliberately so), with local units operating many accounts and activities 'off-budget'. This situation solved problems for the central Party-state by easing some of the burden of service delivery or regulatory functions, and also created problems, by increasing local autonomy. Reformers worried about the ills of 'devolution and localism', as the idea of 'decentralisation' was tainted by a conventional Party-state centralist predisposition. As we see in the next section, however, certain sorts of decentralisation were increasingly both legitimate and convenient.

\section{THE CASE OF SALARY REFORM}

'Salary reform' was identified from the beginning of doi moi as a key area for action. In 1993, a set of simplified salary scales was drawn up and new rates applied to provide for a greater degree of uniformity across types of job and to take account of movements in prices. This new system of steps, based on multiples of a base salary, 
provided the pegs on which to hang a system of grades and ranks in the public service under the Civil Service Code, also promulgated in 1993. Uniform salary scales pegged to length of service and differentiated by job types were a necessary component. In this phase of salary reform, however, the lack of a systematic set of civil service position rules was a less pressing issue than the need to monetise inkind rewards, such as free or heavily subsidised housing, health care and education, which had traditionally formed a major component of the benefits that flowed from being a state employee.

'Salarisation' was a profound change, as it altered the basis of public finance. A parallel change was the shift from relying primarily on extraction of surpluses from state enterprises to a cross-sector tax system. State employees of one kind or another comprised the great bulk of the salary income earners in the economy. But the levels of tax revenue under the evolving new system of public finance were not sufficient to provide for a state budget that would enable both the monetisation of public goods as higher salaries and their provision as 'free', universal public services. ${ }^{5}$ Salarisation thus carried with it the overt expectation that the monetised salary would provide the individual employee with the 'ability to pay', justifying a range of new fees and charges for public services. ${ }^{6}$

Government...by the end of 1992 has roughly salaried allowances for housing, health care insurance, transportation, and eradicated subsidised education (except primary education) and free of charge health care services and treatment, house granting and other high-price subsidy for public servants (Government Steering Committee 2000d:44).

While there were strong doctrinal and practical reasons to continue subsidising some public service provision, such as primary education, the practical issues raised by transition and underdevelopment precluded the possibility of a Western-style, tax-funded welfare state. ${ }^{7}$

Another major problem has been the perceived inadequacy of the official wage in the eyes of most public employees. The standard pay scales were set at a level that did not provide most state employees with what they considered a 'living wage', while the promotion and advancement mechanisms locked most employees into a rigid system of regular but very small increments. This state of affairs generated a myriad of interconnected problems. Among them was the widespread tendency for public employees - health workers and teachers, for example - to move partly into the private sector (while remaining on the public payroll) in order to supplement their income. The occupation of a position in many government agencies is viewed as a launching pad for a variety of private income-earning activities. Local stratagems to cope with low pay have undermined efforts to modernize the system of public administration according to the principles of the 'state ruled by law'. Most local administrative units have found ways to generate 'unofficial' funds so as to top up wages.

Government cannot control all sources of incomes of public servants. Entities decide by themselves allowances for lunch, or additional income for public services taken from state budget or other sources of income generated by additional services (GSC 2000d:50).

Thus, while pay is supposedly uniform and set according to strict levels and 
categories of employment, the real situation is very different. Personnel management is highly decentralised in the state apparatus, and not regulated with a heavy hand by the central personnel agency. ${ }^{8}$ Heads of administrative units (as with political leaders more broadly) often feel a strong obligation towards their workforce, in part a reflection of the importance of patronage in Vietnamese political life. Low pay reproduces some of the conditions under which such patrimonial rather than legalrational norms pervade the civil service.

Thus, in the absence of sufficient resources in the national budget to make a significant impact on the adequacy of the official wage, the operations in practice of the salary system have undermined central discipline and control. Many agencies, and the workers in them, have learnt the ways of self-sufficiency only too well.

[While]...operation of all organisations...is...run from state budget, other financial gains by the organisation are divided among and by themselves. Government completely lost control over additional incomes, although the operation is run [using] the state's assets and by state public servants (Government Steering Committee 2000d:50).

The government clearly acknowledged that the current salary system contained overt incentives to take 'unofficial' local initiatives, to which the centre was forced to turn a blind eye or even to grant its blessing. The dual problem thus emerged of reining in off-budget activities and exerting some kind of discipline over administrative agencies and service delivery units.

In a pattern familiar from the wider reform experience of doi moi, the centre's reforms put the official stamp on a state of affairs that had already been in existence as a result of local 'fence breaking', ', and tried to turn them to the centre's purposes. Given budget scarcity, the very resource mobilisation capacity that led to the indiscipline was picked up as part of the solution. The chosen strategy was officially to sanction and make use of the fact that all public service delivery units were capable of generating income (including what was currently unofficial income) from their productive capacities. Such bodies in a market socialist system were engaging in a new set of social and economic relations outside the boundaries of the state, and for that reason they should neither be subject to administrative interference by line agencies, nor expect 'subsidy'. The state management principle underlying this argument was identical to the one that justified the reconstitution of state owned enterprises into autonomous business units and removal of their 'subsidies' (Painter 2003a). Thus, service delivery units should also have greater autonomy, including in matters of salary, to the extent that their revenue provided such freedom. However, if income-generating public service delivery bodies could in this manner help to solve the problems on the salary reform agenda, 'administrative' agencies, which had no major income sources other than the central budget, needed a rather different approach. For them, the solution was to seek efficiency gains through budgetary and management reform. The common element in both strategies was increased autonomy for local managers.

Thus, a new round of salarisation (this time, of income supplements derived from off-budget local revenue) was envisaged. The means to achieve this was to 
grant income-generating bodies much greater financial and personnel management autonomy within a more complex and transparent set of global budgeting rules, and to establish a new set of allocation rules where subsidisation was needed. These rules would serve the purpose of providing the necessary incentives both for bringing off-budget transactions into the budget, and for funding the next stage of salary reform. Vietnamese reformers arrived at a fashionable global solutiondevolved budgeting, flexible pay scales and accountable management-in the course of working through some very local problems.

This strategy was worked out over a number of years. At first, the problem of low wages was dealt with simply by funding wage increases from the budget, but these rises hardly kept pace with price inflation. In 1993, the monthly basic wage was set at VND120,000 (about US\$8); this was raised to VND144,000 (about US\$10) in 1997, and step by step to VND210,000 (US\$14) in 2001. In seeking to fund further salary increases, one option was to cut staff numbers. The government decided in October 2000 to cut overall staff numbers by 15 per cent by the end of 2002. All administrative units were instructed to submit plans showing how they would achieve the target, albeit with little concrete result. In the meantime, a high-level working group supported by experts in the Ministry of Finance framed a new set of proposals for funding a series of substantial salary increases. On 1 January 2003, the basic salary was raised to VND290,000 (about US\$19), a rise of thirty eight per cent, and from October 2004 to approximately VND380,000 (about US\$25). Half of these pay rises would be funded from the state budget, including savings made by local managers out of downsizing, the rest from revenue raised locally.

For the upcoming salary reform, funds will not only come from the state budget-other avenues like allowing non-productive institutions to use part of their budgets to pay wages, and commercialising the healthcare, education and sport sectors and so forth would contribute. ${ }^{10}$

Separate measures applied to administrative agencies and to revenue-raising or public service delivery agencies respectively. Administrative bodies would now be funded from a lump sum allocation rather than by a funding formula based on existing levels of employment and salaries. The new 'block allocation' is effectively a one-line budget, with all the autonomy that this makes possible, and was first piloted in Ho Chi Minh City, where it led to savings and stimulated restructuring and downsizing. In December 2001, the scheme was extended to a larger number of pilots, with the clear intention to implement it across the state sector. This measure would assist both in meeting the downsizing targets and in paying the higher salary bill

...bearing in mind the current practices, which reveal extreme wastefulness in using funds from the State budget, giving lump sums to State administrative agencies will help promote savings, prevent wastefulness and reserve a part of the sums to improve employees' wages (Quy Hao 2003:15)

The very low level of salaries had ironically contributed to 'waste' through excessive rigidities and 'incremental creep' in staffing levels under the previous 
budget allocation system, with central allocation formulae based largely on the size of the workforce. Local managers sought for the most part not only to protect their employees by resisting downsizing but also to 'pad' their annual request for central budget allocations on the basis of a growing establishment. The additional cost to the official budget of taking on additional staff was very low, while the political costs of downsizing were very high.

One of the potential attractions to the centre of the kind of managerial devolution now being engineered was the expectation that a stronger set of interdependencies would be created as a consequence between local managers and the central managerial and political élite, with a concomitant weakening of the local patronclient relations that are critical to local bosses. The incentives and rewards for managers are now geared more towards taking up a more 'managerialist' stance vis-à-vis employees in pursuit of downsizing and efficiency gains, so as to provide the remaining workforce with their salary increases and supplements. As described below, the new central budget allocation and accounting processes at the same time put new instruments of potential control in the hands of the centre.

This new set of evolving relations between centre and periphery and employer and employee in the state apparatus is seen clearly in the case of public service delivery agencies. Decree 10 of December 2002 granted them extensive budgetary autonomy, allowing them to '(i) manage their own revenue accounts; (ii) adjust salary payments to reward performance; (iii) restructure their staffing to gain efficiency; (iv) set administrative spending norms that are different from those set by the government; and (v) carry forward funds unspent in the previous year' (Cuvillier and Hoan Van Hai 2002). In the course of implementing this so-called 'financial self-determination mechanism', each public service delivery agency would be classified according to their revenue generating capacities, and the amount of state budget funding (if any) would be calculated and fixed for three years (with a 'markup' factor to cover cost increases). At the same time as the cost of salary increases was passed down to local managers and the capacity provided to meet it from internal budgets, the discretion was granted to managers to pay above-award rates to reward efficiency-improving performance.

Thus, by a series of self-reinforcing steps, the government moved rapidly in 2001-02 towards a far more devolved system of financial and personnel management, in which local revenue-raising would play a growing role. But this was not the whole story, for the measures also forced local managers to 'open their books' and removed some (but not all) of the incentives to conceal 'off-budget' activities, in effect legitimising previously informal arrangements. ${ }^{11}$ The aim of greater control and discipline was also to be achieved by new budget reporting and monitoring requirements. ${ }^{12}$ Part of the 'package' of devolved accountable management everywhere is the substitution of ex ante input controls by ex post output controls, coupled with audit of financial transactions-that is, old, counterproductive systems of control are replaced by new ones, including measures to improve efficiency. The centre, however, retained a number of strict controls, limits 
and thresholds such that the granting of autonomy was within clear constraints. Among the latter were a set of measures to limit and monitor local fees and charges in order to retain some level of uniformity and to prevent local abuses. Despite this, a possible adverse consequence of the package did not go unnoticed by outside observers

...the government articulates a welcome commitment to improve the system of exemptions for education costs and the provision of free health services to poor households, (but) this may conflict with the recently-issued Decree 10...The concern here is that managers...will not be receiving the clear and consistent message that it is a high priority of government to ensure that poor people receive free primary education and curative health care (International Monetary Fund 2002:9)

\section{OUTSIDE INFLUENCES}

While clearly dealing with a set of problems that were rooted in Vietnam's historical development, the most recent salary reform measures echo themes and models that are very familiar in the global context of contemporary administrative reform, revolving around

- an increasingly decentralised system of pay and rewards, with increased management discretion

- overt reference to 'market rates' and 'ability to pay' in different employment environments

- use of differential rates of pay or 'bonuses' as an incentive mechanism to reward performance.

So what role should we attribute to the use of solutions brought in from outside Vietnam?

The overseas development aid (ODA) program has been a primary and direct source. According to the World Bank Development Indicators, annual ODA to Vietnam averaged 20 per cent of annual central government expenditures between 1994 and 1999, rising to 27 per cent in 1999. Aid has increasingly focused on 'governance', under which public administration reform is subsumed, although significant amounts of governance-focused aid only began to flow in after the adoption of the Master Program. Prior to that, Vietnam had only received some US\$23 million for twelve separate projects related to public administration reform (Thang Van Phuc 2001). Among them was a series of UNDP projects beginning in 1991, the most prominent of which provided technical assistance for the conduct of the PAR Review in 2000. Since 2001, UNDP and bilateral donor programs have continued, but significant ADB and World Bank loans have also been approved, accompanied by technical assistance with central coordination of public administration reform, provision of IT infrastructure, civil service training, and reform of public finances among other projects.

The Vietnamese government, in an attempt to deal with what it perceived to be specifically local problems, set the broad outlines and objectives of the public administration reform program. The program, as such, was not 'imposed', nor was it delivered ready-made by a set of external donors or advisers under any kind of duress. One component of the public administration reform, salary reform, was not 
nominated by the government as a high priority for direct donor aid and technical assistance. The issue is highly sensitive politically, and goes to the core of issues of Party control, state capacity and political stability. Many donors, notably the World Bank, moreover, were perceived as having a doctrinaire and unhelpful approach to the issue based on recommendations such as radical downsizing and privatisation, presented in an ideologically insensitive manner. As we have seen, the local experts were not, as a result, inhibited from selecting from some of the same solutions, but the process of local control was vital.

The influence of donors and their advisers has been more direct in other, related parts of the public administration reform agenda. The technical experts of the Ministry of Finance who provided significant input to the salary reform issue were already involved in quite extensive dialogue with international consultants over other issues of budgetary and financial reform. Such projects were among the more popular with aid donors. A stocktake in 2001 listed eight separate aid projects and ten IMF or World Bank missions on budgeting and financial management since 1996, claiming significant results.

Following the first Government-donor Public Expenditure Review in 2000 (PER-2000), the Government adopted in 2001 a comprehensive program to strengthen public expenditure management. The aim is to improve comprehensiveness, consistency and transparency of budgetary information as well as equity and efficiency of public spending (World Bank 2002b:30)

International consultants and local experts working directly with the Ministry of Finance in projects associated with the Public Expenditure Review have played an active role in disseminating ideas and responding to government proposals on financial reform. ${ }^{13}$ Their role as a conduit for international 'best practice' models of public financial management cannot be dismissed. Moreover, these models are quite precise and well articulated, achieving a high level of consensus in the donor and international consultancy community (see, for example, Allen and Tommasi 2001; OECD 1998). Thus, although the government and Party wished to retain control of the agenda of problems being defined as critical, they were more than willing to be exposed to the technical detail and rationales embodied in particular solutions. Of course, experts in the Ministry of Finance hardly needed international consultants to bring the latest models of budgetary and financial management best practice to their awareness, and international textbooks could have provided the menu of contemporary thinking about devolved management, output budgeting, lump sum or one-line allocations and user charges. However, the strong involvement of World Bank, UNDP and other advisers and consultants in the budgetary reform process also directly exposed the Ministry of Finance to the global discourse of contemporary financial management.

\section{CONCLUSION}

Analysis of the wider public administration reform agenda showed the significance 
of themes and doctrines that related problems on the ground to wider themes of evolving Party doctrine. However, in the specific case of salary reform, both the problem definitions and the canvassing of available solutions were mainly concerned with practical dimensions of fiscal capacity and administrative control. Perhaps the strongest doctrinal influence had a somewhat perverse outcome, in that the carefully articulated doctrine of socialisation came to be coupled with more extensive use of user fees for collective goods levied on family or private income. The recourse to user fees and charges was tempered by state subsidy for basic, essential services but the overall design principles evinced a decidedly individualistic, marketdriven 'capacity to pay' principle of service access. While this was carefully married with the more communitarian rhetoric of self-help or co-production, including the careful choice of the term 'socialisation', the rhetoric provided only the thinnest of veneers over what was effectively a process of commercialisation.

The adoption and adaptation of tools such as user charges and devolved budgets had very particular local implications and meanings, but also brought reformers in touch with a global reform discourse. The evidence, however, demonstrating that the proponents and purveyors of this discourse had either direct or indirect influence is mixed. On the one hand, the case of salary reform suggests that the reformers were brought to adopt these solutions by the logic of local circumstance and convenience, but overseas models and experience, particularly with financial management tools, provided at least part of the solution eventually adopted. There is, however, a twoway process in the relations with consultants and donors. Vietnamese reformers' receptivity to the concepts of modern public sector management saw adoption of particular ideas from overseas but also generated commitment among the donors funding reform implementation. The significance of this strategic aspect of reform adoption is a subject for further research, but a similar strategic relationship has been observed in other contexts, such as poverty reduction (Painter 2005). For the Vietnamese government, controlling the agenda of problem definition and the scope of the imported solutions while also tapping generous overseas aid donations, is critical.

The pattern of borrowing and transplantation that I have described has similarities with the phenomenon of 'cropping up', discussed earlier. The definition of the problems arose from a local debate about some fundamental issues of deep concern to the Party and top state officials, who were intent on achieving and maintaining control over state resources and capacities, while the internationally familiar menu of budgetary reform and devolved management offered solutions to these locally identified problems. Cropping up is both a process of reproduction or borrowing and of transformation. The use of parts of one administrative system's 'toolkit' of measures in another can be expected to produce anomalies and paradoxes. As noted earlier, the doctrine and practices of democratic centralism do not admit significant formal political devolution, although quite significant decentralisation was built into the tiered system of provincial and district administration. The 
unintended consequences of relaxing controls of the command economy and the attempt to build new systems of administration in the 1990s in some respects added to the power and autonomy of local units-for example, the greater reliance on local revenues put new patronage and other discretionary powers in the hands of local leaders. The new forms of devolution envisaged in the most recent salary reforms are coupled with a set of financial controls with the hope of undermining these sources of local power. In other words, paradoxically, the techniques of devolved, accountable management are being appropriated to an agenda concerned with enhancing discipline and control. Whether the design realises this objective remains to be seen, particularly in the light of the weak institutionalisation of the rules in the first place. It is just as likely to result in a new set of local unofficial stratagems and their attendant irregularities.

While the dynamics of the cropping up and the development of local hybrids suggest a Vietnamese-controlled process of reform, the longer-term implications for retaining control of the outcomes may be more uncertain. Once the 'problem' (for example, of salary reform) gets defined in terms of one set of solutions rather than another, the problem-solving and policymaking processes may become set on a course of action that carries them forward to unexpected destinations. The 'whole' that results may take on a character that each of its parts was originally disconnected from in the process of selecting pragmatically from the menu. Local actors have slipped imperceptibly and naturally into talk of 'commercialisation', when original thinking conceived of the same thing as 'socialisation', and in the process they may help transform it. Despite being adapted and transformed to suit local conditions, the borrowing of transnational administrative tools and rationales by local actors intent on furthering their own schemes has the potential to bring with it modes of thought and techniques of improvement that have new logics, and inject new resources and opportunities into the local scene, with potentially unpredictable consequences.

Thaveeporn Vasavakul (1996) and Adam Fforde (2002) have argued that the importation of external ideas drawn from the developmental experience of nonsocialist states is more than just a temporary, tactical concession within an unreconstructed Communist doctrinal worldview, but part of a more fundamental rethinking by state leaders that serves to reconstruct their power on a new footing. That is, as Alexander Woodside suggests in the quotation at the head of this chapter, the results of borrowing and transplantation may be evidence less of a process of global homogenisation than of new forms of local enablement. ${ }^{14}$ At the same time, the second and third-order consequences may yet be more profound, as digging the ground for a reformed public administration system of transplants and hybrids may have uprooted more than was intended.

\section{ACKNOWLEDGMENTS}

Research for this chapter was conducted with the support of City University of 
Hong Kong Projects 7100218 and 9030995.

\section{NOTES}

1 The purpose is not to identify all external sources and weigh their respective influence. For example, no direct reference is made in this chapter to the lessons learnt from China. The contemporary western discourse on administrative reform is selected as a case to explore the results of interaction between local problem solving and outside ideas.

2 This has been the case in the administrative reform process in Vietnam. As early as 1991, a UNDP mission was providing stimulus to local debate and helping shape discussion. Since then, both bilateral donors and the international institutions have been quite active in public administration reform.

3 There is much overlap between these two lists. It is clearly not feasible to extract from a unified text two identifiably distinct sets of 'local' and 'foreign' proposals. These examples are chosen because they suggest strong traces and echoes from different sources.

4 The review was set up by government decision under the guidance of the PAR Steering Committee, which was located in the Office of Government. Five groups were established, covering different aspects of public administration reform. The groups drew on technical assistance from a small number of international consultants, provided with the help mainly of UNDP funding, and three workshops were held in May 2000 to allow national and provincial senior officials to make a contribution. Official Vietnamese and English language versions were released together in June 2000, and are available on the UNDP Vietnam Office website. The reviews formed an important input for a subsequent major announcement on public administration reform, and a new set of national programs, in September 2001.

5 The introduction of income and consumption taxes lagged behind 'salarisation', and their ineffective implementation accentuated the problem.

6 The same logic applied to rural workers who were given 'property rights' over formerly collectivised farming land. The economic proceeds of making use of those rights would provide the wherewithal for individual households to pay for those services formerly provided as one of the benefits of membership of the collective. Regulations on fee exemptions were introduced to cushion the impact on the very poor.

7 The current situation is that families account for about 80 per cent of the total health budget, as against the state's 20 per cent. In education, public subsidies provided respectively 61 per cent of primary, 42 per cent of lower secondary, 33 per cent of upper secondary and 46 per cent of higher and vocational education expenditure (World Bank 2001)

8 Oversight by the Party is another matter, albeit through a layered system of Party committees at the appropriate levels.

9 The importance of 'fence breaking' as a pattern of bottom-up reform is widely acknowledged in the literature on doi moi. Where the centre is indecisive or merely cautious, a 'blind eye' may be turned to 'illegal' local solutions and initiatives that, if effective, provide a momentum to wider reform following the granting of official blessing.

10 Quach Duc Phap, Director, Department of Fiscal Policy, quoted in Quy Hao (2003:15).

11 Additional potential side-benefits include a better set of accounting mechanisms to check fraud and corruption.

12 The 'modernisation' project of the public administration reform program also involves establishing effective databases and information systems pertaining to personnel and financial transactions in order to facilitate this control.

13 UNDP Project 96028 Phase II is located in the Ministry of Finance. Its objectives are: 'to build the capacity to conduct a public expenditure review at the central government level; to enable three provincial governments to undertake periodic public expenditure reviews, and disseminate the results and experience to other provinces; to improve the ability of the Ministry of Finance, key sector ministries and other relevant agencies to better prepare budget'. It claims the following 'results': 'improved understanding among senior government staff at all levels of the use of a PER as a tool for improving resource allocation and strengthening the budget allocation process; a core group of staff in relevant ministries and pilot provinces trained in public expenditure analysis; PER guidelines set up; PER implemented; a medium-term expenditure 
framework established; recommendations for improvement of PER system'.

14 On globalisation as an 'enabling' process, see Weiss (2003:15-19).

\section{REFERENCES}

Allen, R. and Tommasi, D., 2001. Managing Public Expenditure: a reference book for transition countries, Organisation for Economic Cooperation and Development, Paris.

Bennett, C.J., 1991. 'Review article: what is policy convergence and what causes it?', British Journal of Political Science, 21(2):215-33.

Beresford, M., 2001. 'Vietnam, the transition from central planning', in G. Rodan, K. Hewison and R. Robison (eds), The Political Economy of South-East Asia, Oxford University Press, Melbourne:206-30.

Brunsson, N., 1998. 'Homogeneity and heterogeneity in organization forms as the result of cropping-up processes', in N. Brunsson and J.P. Olsen (eds), Organizing Organizations, Fagbokforlaget, Oslo:259-78.

Christensen, T. and Laegreid, P., 2001. 'A transformative perspective on administrative reforms', in T. Christensen and P. Legreid (eds), New Public Management: the transformation of ideas and practice, Ashgate, Aldershot:13-42.

Cohen, M.D., March, J.G. and Olsen, J.P., 1972. 'A garbage can model of organizational choice', Administrative Science Quarterly, 17(1):1-25.

Common, R., 2001. Public Management and Policy Transfer in Southeast Asia, Ashgate, Aldershot.

Cuvillier, E. and Hoan Van Hai, 2002, 'What's going on regarding "Decree 10" implementation?', United Nations Development Programme, Hanoi. Available online at http:/ / www.undp.org.vn/projects/vie96028/index.htm [accessed February 2003].

Do Muoi, 1995. Address of the Secretary General of the Communist Party of Vietnam to the Eighth Party Plenum of the Seventh Congress, Hanoi, 16 January.

Dolowitz, D. and Marsh, D., 1996. 'Who learns what from whom? A review of the policy transfer literature', Policy Studies, 44(2):342-57.

Fforde, A., 1993. 'The political economy of "reform" in Vietnam-some reflections', in B. Ljunggren (ed.), The Challenge of Reform in Indochina, Harvard University Press, Havard:293-322.

- 2002. 'Light within the ASEAN gloom? Vietnam's economy since the Asian Financial Crisis', in D. Singh and A.L. Smith (eds), Southeast Asian Affairs 2002, Institute of Southeast Asian Studies, Singapore:357-77.

Gainsborough, M., 2003. 'Corruption and the politics of economic decentralisation in Vietnam', Journal of Contemporary Asia, 33(1):69-84.

Government of Vietnam, 2001, Master Programme on Public Administration Reform for the Period 2001-2010 (attachment to the Prime Minister's Decision No.136/ 2001/QD-TTg of 17 September 2001), Government of Vietnam, Hanoi.

Government Steering Committee for Public Administration Reform, 2000a. The 
Overall Report: review of public administration reform, Government of Vietnam, Hanoi.

, 2000b. Report of Group 1: stances and guidelines of the Party and the State of Vietnam on public administration reform, Government of Vietnam, Hanoi.

_ 2000c. Report of Group 3: review of public administration reform in the field of organizational structure of the government apparatus and state managementroles, functions, responsibilities and structure, Government of Vietnam, Hanoi.

- 2000d. Report of Group 4: review of public administration reform in the field of human resource management and development (applicable to civil and public servants), Government of Vietnam, Hanoi.

Halligan, J., 1996. 'The diffusion of civil service reform', in H. Bekke, J. Perry and T. Toonen (eds), Civil Service Systems in Comparative Perspective, Indiana University Press, Bloomington:288-317.

International Monetary Fund, 2002. Joint Staff Assessment of the Poverty Reduction Strategy, Prepared by the staffs of the International Monetary Fund and International Development Association, International Monetary Fund, Washington, DC.

Kingdon, J., 1984. Agendas, Alternatives and Public Policies, Little Brown, Boston.

Larmour, P., 2002. 'Conditionality, coercion and other forms of "power": international financial institutions in the Pacific', Public Administration and Development, 22(3):249-60.

Organization for Economic Cooperation and Development, 1998. User Charging for Government Services: Best Practice Guidelines and Case Studies, PUMA Occasional Paper 22, Organization for Economic Cooperation and Development, Paris.

Painter, M., 2003. 'The politics of economic restructuring in Vietnam: the case of state-owned enterprise "reform"', Contemporary Southeast Asia, 25(1):20-43.

— 2005. 'The politics of state sector reform in Vietnam: contested agendas and uncertain trajectories', Journal of Development Studies, 41(2):261-83.

Quy Hao, 2003. 'Easing the burden on exchequer', Vietnam Economic Times, February:15.

Thang Van Phuc, 2001, Promoting Public Administration Reform and Priorities for Calling Donor Assistance set out by the Government of Vietnam, Presentation by Vice-Chairman GCOP, Consultative Group Meeting, Hanoi, 7-8 December.

United Nations Development Programme, 2001. Modernizing Governance in Vietnam, United Nations Development Programme, Hanoi.

— 2002. PAR Master Programme: results and learning, 2001-2002, Ministry of Home Affairs and UNDP Joint Paper for the Vietnam Consultative Group Meeting, United Nations Development Programme, Hanoi.

Vasavakul, T., 1996. 'Politics of the reform of state institutions in the post-socialist era', in Suiwah Leung (ed.), Vietnam Assessment: creating a sound investment climate, Curzon Press/Institute of Southeast Asian Studies, Singapore:42-68.

—, 2002. Building Authority Relations: public administration reform in the era of Doi 
Moi, Asian Development Bank, Hanoi. Available online at http:// www.aduki.com.au/.

Watson, A., 2001. Society and Legal Change, Temple University Press, Philadelphia

Weiss, L., 2003. 'Introduction: bringing domestic institutions back in', in L. Weiss (ed.), States in the Global Economy: bringing domestic institutions back in, Cambridge University Press, Cambridge:1-36.

Woodside, A., 1997. 'The struggle to rethink the Vietnamese state in the era of market economics', in T. Brook and Hy V. Luong, Culture and Economy: the shaping of capitalism in Eastern Asia, The University of Michigan Press, Ann Arbor.

World Bank, 2001. Vietnam: managing public resources better, public expenditure review 2000, Joint Report of the Government of Vietnam-Donor Working Group on Public Expenditure Review, World Bank, Washington, DC

_ 2002a. Development Report 2003: Vietnam delivering on its promise, World Bank, Hanoi.

_- 2002b. Taking Stock: an update on Vietnam's economic reforms— progress and donor support, Mid-year Consultative Group Meeting, Ho Chi Minh City, 23-24 May. 